\title{
Chemical characterization, antioxidant and antimicrobial activity of propolis obtained from Melipona quadrifasciata quadrifasciata and Tetragonisca angustula stingless bees
}

\author{
A.R. Torres ${ }^{1,2}$, L.P. Sandjo ${ }^{3}$, M.T. Friedemann ${ }^{2}$, M.M. Tomazzoli ${ }^{4}$, M. Maraschin ${ }^{4}$, C.F. Mello ${ }^{1}$ and \\ A.R.S. Santos ${ }^{1,2}$ \\ ${ }^{1}$ Programa de Pós-graduação em Farmacologia, Centro de Ciências da Saúde, Universidade Federal de Santa Maria \\ Santa Maria, RS, Brasil \\ ${ }^{2}$ Laboratorio de Neurobiologia da Dor e Inflamação, Departamento de Ciências Fisiológicas, Centro de Ciências Biológicas, \\ Universidade Federal de Santa Catarina, Florianópolis, SC, Brasil \\ ${ }^{3}$ Departamento de Ciências Farmacêuticas, Centro de Ciências da Saúde, Universidade Federal de Santa Catarina, \\ Florianópolis, SC, Brasil \\ ${ }^{4}$ Laboratório de Morfogênese e Bioquímica Vegetal, Centro de Ciências Agrárias, Universidade Federal de Santa Catarina, \\ Florianópolis, SC, Brasil
}

\begin{abstract}
In this study, we investigated the chemical composition, and antioxidant and antibacterial properties of ethanolic extracts of propolis (EEP) from Melipona quadrifasciata quadrifasciata and Tetragonisca angustula. Chemical composition of EEP was determined by colorimetry and chromatographic (HPLC-DAD and UPLC-Q/TOF-MS/MS) analysis. Antimicrobial activity of EEP was evaluated against gram-positive (S. aureus, methicillin-resistant $S$. aureus, E. faecalis) and gram-negative (E. coli and K. pneumoniae) bacteria by the minimal inhibitory concentration (MIC) test using the microdilution method. Furthermore, the growth curve and integrity of cell membrane of $S$. aureus and $E$. coli were investigated using standard microbiological methods. HPLC-DAD analysis showed that the EEP of $M$. quadrifasciata quadrifasciata has a more complex chemical composition than the EEP of $T$. angustula. Moreover, UPLC-MS analyses of $M$. quadrifasciata quadrifascita indicated flavonoids and terpenes as major constituents. The bactericidal activity of both EEPs was higher against gram-positive bacteria than for gram-negative bacteria. The EEP from $M$. quadrifasciata quadrifasciata presented MIC values lower than the EEP from $T$. angustula for all tested bacteria. The EEP from M. quadrifasciata quadrifasciata caused lysis of the bacterial wall and release of intracellular components from both $E$. coli and $S$. aureus. Our findings indicate that the chemical composition of propolis from stingless bees is complex and depends on the species. The extract from M. quadrifasciata quadrifascita was more effective against grampositive than gram-negative strains, especially against $S$. aureus and methicillin-resistant $S$. aureus compared to $T$. angustula extract, by a mechanism that involves disturbance of the bacterial cell membrane integrity.
\end{abstract}

Key words: Stingless bees; Propolis; Antimicrobial activity; S. aureus; M. quadrifasciata quadrifasciata; T. angustula

\section{Introduction}

Propolis is a complex mixture of pollen and resinous and balsamic substances collected by bees from buds, flowers, and plant exudates, and bee salivary secretions (1). Since propolis is a bee product of plant origin, its chemical composition and biological activity depends on the specificity of the local flora, season of harvest, and bee species (2-4).

Different biological and therapeutic properties have been reported for propolis, including antioxidant $(3,5)$, antiinflammatory $(5,6)$, immunomodulatory $(7,8)$, antitumoral $(8,9)$, and antimicrobial activities $(2,7,10,11)$ among others. It has been shown that propolis has bactericidal and bacteriostatic activity against various gram-positive bacteria, such as $S$. aureus, $S$. mutans and $B$. subtilis, and gram-negative bacteria, including $E$. coli, K. pneumoniae and $P$. aeruginosa $(6,7,9,10)$. Moreover, a synergistic inhibitory effect of propolis and antibiotics on the growth of $S$. aureus has been reported (11). Such an antimicrobial activity of propolis is particularly relevant if one considers the increasing emergence 
of antibiotic-resistant microorganisms in hospitals and in the community (11). This situation is aggravated by the inadequate use and prescription of antibiotics and the scarcity of new drugs (12).

Most of the studies in the literature have investigated the antimicrobial activity of the propolis produced by Apis mellifera. However, little is known about the biological effects of the propolis produced by other bees, such as the Meliponines. Melipona quadrifasciata quadrifasciata Lepeletier and Tetragonisca angustula Letreille stingless bees belong to the Meliponini tribe, and are two among more than 200 species of Brazilian native stingless bees (13). Native from tropical and subtropical regions, M. quadrifasciata quadrifasciata and Tetragonisca angustula are locally known as Mandaçaia and Jataí, respectively. Interestingly, the propolis from $M$. quadrifasciata quadrifasciata is known as geopropolis because it presents soil traces in its composition (14). Due to the unique behavioral and morphological characteristics of these bees, one might reasonably hypothesize that the propolis produced by them has distinct composition and biological activity. Thus, the aim of this work was to characterize the chemical composition of the ethanolic crude extract of propolis (EEP) produced by $M$. quadrifasciata quadrifasciata and $T$. angustula and investigate its potential antioxidant and antibacterial activity against gram-negative and gram-positive bacteria, including methicillin-resistant $S$. aureus.

\section{Material and Methods}

\section{Chemicals and reagents}

DPPH (2,2-diphenyl-1-picrylhydrazyl), resazurin, FolinCiocalteu phenol reagent $(2 \mathrm{~N})$, gallic acid monohydrate $\left(\mathrm{C}_{7} \mathrm{H}_{6} \mathrm{O}_{5} \cdot \mathrm{H}_{2} \mathrm{O}\right)$, quercetin, aluminum chloride $\left(\mathrm{AlCl}_{3}\right)$ and sodium carbonate $\left(\mathrm{Na}_{2} \mathrm{CO}_{3}\right)$ were purchased from Sigma (USA). Ethanol and methanol were obtained from Merck (Brazil). Acetonitrile was from Tedia (Brazil). The culture medium Brain Heart Infusion was obtained from Himedia (India). The bacteria strains were obtained from Laborclin (Brazil) and Microbiology Laboratory of the Federal University of Santa Maria (Brazil). All other chemicals were of analytical grade and purity. Aqueous solutions were prepared in ultrapure water produced by a Milli-Q system (18.2 M $\Omega$, Millipore, France).

\section{Propolis samples and ethanolic extract preparation}

The samples were collected in September of 2014 in Rio das Antas, Brazil. Five samples of the propolis from M. quadrifasciata quadrifasciata and three samples from $T$. angustula were obtained from the inner parts of the beehives. The ethanolic extract was prepared as reported by Park et al. (15). Two grams of the powder was mixed with $25 \mathrm{~mL}$ of $80 \%$ ethanol in a sealed container protected from light (to avoid loss of volatile and photosensitive compounds), under agitation in a water bath at $70^{\circ} \mathrm{C}$ for $30 \mathrm{~min}$. After extraction, the mixture was filtered (grade 1 Whatman) to obtain the EEP at concentration of $80 \mathrm{mg} / \mathrm{mL}$ (propolis: ethanol $80 \%, w / v)$.

\section{Total polyphenol and flavonoid contents}

The total polyphenol content of EEP was determined using the Folin-Ciocalteu colorimetric method described by Frozza et al. (16). Briefly, $100 \mu \mathrm{L}$ of the hydroalcoholic extract $(1 \mathrm{mg} / \mathrm{mL}$ ) was mixed with $500 \mu \mathrm{L}$ of Folin-Ciocalteu and after $5 \mathrm{~min}$ in dark, $400 \mu \mathrm{L}$ sodium carbonate $(7.5 \%)$ was added. After incubation in the dark at room temperature for $30 \mathrm{~min}$, the absorbance of the reaction mixture was measured at $765 \mathrm{~nm}$ in a spectrophotometer (model FlexStation, Molecular Devices, USA). Gallic acid standard solutions $(0.25-4.0 \mu \mathrm{L} / \mathrm{mL})$ were used for the calibration curve. The average of three readings was used to determine the total polyphenol content, reported as $\mathrm{mg}$ of gallic acid equivalents per $\mathrm{g}$ of propolis (GAEs).

The total flavonoid content in EEP was determined by the method described by Campos et al. (9). For this, $0.5 \mathrm{~mL}$ of EEP $(100 \mu \mathrm{g} / \mathrm{mL})$ was mixed with $4.5 \mathrm{~mL}$ of $2 \%$ aluminum chloride hexahydrate in methanol. After 30-min incubation at room temperature in the dark, the absorbance was read at $415 \mathrm{~nm}$ using a plate spectrophotometer (FlexStation, Molecular Device). Quercetin $(0.4-11 \mu \mathrm{g} / \mathrm{mL})$ was used as standard. Triplicates were used to determine the flavonoid content, reported as $\mathrm{mg}$ of $\mathrm{QE}$ per $\mathrm{g}$ of propolis.

\section{High performance liquid chromatography (HPLC-DAD) analysis}

Briefly, $10-\mu \mathrm{L}$ samples of EEP were injected in the liquid chromatographer (Thermo Scientific Dionex UltiMate 3000, USA), equipped with a C18 reverse phase column (BioBasic-18, $150 \mathrm{~mm} \times 4.6 \mathrm{~mm} \varnothing, 5 \mu \mathrm{m}$ ) thermostatized at $40^{\circ} \mathrm{C}$ and diode array detector. Elution occurred with a flow rate of $0.8 \mathrm{~mL} / \mathrm{min}$ using a linear gradient of a formic acid aqueous solution $0.5 \%(\mathrm{v} / \mathrm{v})$ (solvent $A$ ) and methanol (solvent B) as follows: (0-10 min) 15\% B, (10-55 min) gradual increase to $70 \% \mathrm{~B}$ and $(55-60 \mathrm{~min})$ gradual reduction to $15 \% \mathrm{~B}$. The identification of the phenolic compounds was carried out by comparing the retention time of the samples with pinocembrin, quercetin, $\rho$-coumaric acid, chrysin, gallic acid, and artepillin $\mathrm{C}$ standards.

\section{Ultra performance liquid chromatography (UPLC) analysis/ESI-QTOF-mass spectrometry (MS)}

The propolis extract $(1 \mathrm{mg} / \mathrm{mL})$ was filtered with a syringe filter $(13 \mathrm{~mm}, 0.22 \mu \mathrm{m}$, Analítica, Brazil) before the analysis. Chromatographic separation was carried out in an Acquity UPLC system class $\mathrm{H}$ (Waters, USA) equipped with a PDA 9-detector, sample manager, and a quaternary solvent manager as well as a BEH C18 column: $100 \mathrm{~mm}$, $1.0 \mathrm{~mm}$, particle size $1.7 \mu \mathrm{m}$ (Waters). The temperature of the column and the sample tray were $40^{\circ} \mathrm{C}$ and $20^{\circ} \mathrm{C}$, respectively. The gradient used for the separation (flow rate of $0.3 \mathrm{~mL} / \mathrm{min}$ ) was composed of $\mathrm{A}$ [water/formic acid, 
99.9/0.1 (v/v)] and B (acetonitrile). The elution was made as follows; $0.0-4.9 \mathrm{~min} 50 \%$ of $A ; 5-9 \operatorname{min~} 40 \%$ of $A$; 9.1-12 $\min 10 \%$ of $A ; 12.1-14.9$ min $5 \%$ of $A ; 15-20$ min $95 \%$ of $A$. The injection volume was $2 \mu \mathrm{L}$.

Mass data were recorded on a Xevo G2-S QTof (Waters) equipped with an electrospray ionization source operating in positive $(\mathrm{ESI}+)$ and negative (ESI-) ion modes using the following instrument settings: nebulizer gas: nitrogen; cone gas flow $10 \mathrm{~L} / \mathrm{h}$; desolvation gas flow $900 \mathrm{~L} / \mathrm{h}$; sampling cone $40 \mathrm{~V}$; source offset $80 \mathrm{~V}$; collision gas: argon; Lockspray reference sample: Leucine enkephalin. Lock masses are m/z 556.2771 (ESI + ) and m/z 554.2615 (ESI-).

$L C$ infusion $(E S I+)$. The desolvation and source temperatures were set at 300 and $90^{\circ} \mathrm{C}$, respectively. The capillary voltage was set to $3 \mathrm{kV}$. Data were collected between 100 and $1200 \mathrm{Da}$, with a scan time of $1.0 \mathrm{sec}$ over an analysis time of $20 \mathrm{~min}$. The LC-MS/MS analyses were performed with a collision energy of $25 \mathrm{eV}$.

LC infusion (ESI-). The desolvation and source temperatures were set at 300 and $90^{\circ} \mathrm{C}$, respectively. The capillary voltage was set to $2.5 \mathrm{kV}$. Data were collected between 100 and $1200 \mathrm{Da}$, with a scan time of $1.0 \mathrm{sec}$ over an analysis time of $20 \mathrm{~min}$. The LC-MS/MS analyses were performed with a collision energy of $25 \mathrm{eV}$. Data was processed with the MassLynx V4.1 software (Waters).

\section{Antioxidant activity}

The DPPH free radical scavenging activity was measured according to Campos et al. (9), with minor modifications. Briefly, $150 \mu \mathrm{L}$ of various concentrations of EEP were mixed with $150 \mu \mathrm{L}$ of DPPH stock solution [80 $\mu \mathrm{mol} / \mathrm{L}$ in ethanol at $80 \%(\mathrm{v} / \mathrm{v})]$. The mixture was incubated at room temperature in the dark for $20 \mathrm{~min}$ and absorbance was measured at $517 \mathrm{~nm}$ in a plate spectrophotometer (FlexStation, Molecular Devices). Extract concentrations were plotted against respective inhibition of DPPH reduction and $\mathrm{IC}_{50}$ was estimated by nonlinear regression using data from three independent experiments carried out in triplicate.

Determination of minimal inhibitory concentration (MIC) The MIC of EEP against S. aureus (ATCC 25923), methicillin-resistant $S$. aureus (MRSA, clinic isolate), E. faecalis (ATCC 29212), E. coli (ATCC 25922), and K. pneumoniae (ATCC 23883) was determined by the broth microdilution method, which was performed according to the Clinical and Laboratory Standards Institute - CLSI M.07-A.9 (17), with minor modifications. The bacterial strains were inoculated in Brain Heart Infusion $(\mathrm{BHI})$ broth with different concentrations of EEP $(16-0.25 \mathrm{mg} / \mathrm{mL})$ in 96-well microplates and incubated at $37^{\circ} \mathrm{C}$ for $24 \mathrm{~h}$. The bacterial inoculum density was adjusted to $10^{8} \mathrm{CFU} / \mathrm{mL}$ according to the $0.5 \mathrm{MacF}$ arland scale and diluted to obtain a final concentration of $5 \times 10^{5} \mathrm{CFU} / \mathrm{mL}$. After $24 \mathrm{~h}$ of incubation, $30 \mu \mathrm{L}$ of resazurin at $0.01 \%(\mathrm{w} / \mathrm{v})$ was added and after $30 \mathrm{~min}$ the samples were visually inspected (18). The color change from purple to pink was recorded as positive bacterial growth. The inoculated medium was used as positive control (growth control), culture medium was used as negative control (sterility control), and a diluent control was made in each experiment. The MIC was considered as the lowest concentration of EEP that inhibited growth. Five independent experiments were performed for each bacterial strain.

\section{Growth curve}

The growth curve assay was used to investigate the bactericidal effects of EEP $(0,0.5,1$, or $2 \mathrm{MIC})$ over time $(0,2,4,6,8,12$, and $24 \mathrm{~h}$ intervals). For this, $100 \mu \mathrm{L}$ of EEP and $100 \mu \mathrm{L}$ of bacterial inoculum, both previously diluted in $\mathrm{BHI}$ broth. The inoculum was diluted to obtain a final concentration of $5 \times 10^{5} \mathrm{CFU} / \mathrm{mL}$. After each incubation, $10 \mu \mathrm{L}$ resazurin $(0.01 \%)$ was added to the withdrawn sample and the mixture was incubated at room temperature in the dark for $5 \mathrm{~min}$. The mixture was then centrifuged at $10,000 \mathrm{~g}$ for $10 \mathrm{~min}$ at room temperature and the absorbance of the supernatant was measured at $550 \mathrm{~nm}$.

\section{Integrity of cell membrane}

The bacterial cell membrane integrity was assessed by measuring the release of cell constituents into supernatant according to Diao et al. (19), with minor modifications. Bacterial cultures $(100 \mathrm{~mL})$ were incubated overnight at $37^{\circ} \mathrm{C}$ and centrifuged at $3500 \mathrm{~g}$ for $15 \mathrm{~min}$ at room temperature, washed three times and resuspended in $0.1 \mathrm{M}$ phosphate buffer solution (PBS, $\mathrm{pH} 7.4$ ). The cell suspension absorbance was adjusted to 0.5 at $620 \mathrm{~nm}$ with PBS. Two hundred microliters of $0.1 \mathrm{M}$ PBS (negative control, $0 \mathrm{MIC}$ ) or EEP (1 MIC) were added to $1.8 \mathrm{~mL}$ of bacterial suspension. The suspensions were incubated at $37^{\circ} \mathrm{C}$ for $4 \mathrm{~h}$, with periodic agitation. Samples were then centrifuged at $11,000 \mathrm{~g}$ for $5 \mathrm{~min}$ at $4^{\circ} \mathrm{C}$ and $200 \mu \mathrm{L}$ of the supernatant was removed to assess the released content (largely nucleic acids) by measuring absorbance at $260 \mathrm{~nm}$ (SpectraMax, Molecular Devices). Absorbance values were corrected using adequate control blanks containing EEP and PBS ( $\mathrm{pH} 7.4)$.

\section{Statistical analysis}

Data were analyzed by the $t$-test or one-way ANOVA followed by Bonferroni's test depending on the number of groups. $I C_{50}$ was determined by nonlinear regression. All analyses were performed using GraphPad Prism version 6.07 for Windows, GraphPad Software, USA.

\section{Results}

\section{Total polyphenol and flavonoid content}

The polyphenol content was $3.87 \pm 0.32$ and $1.26 \pm$ $0.17 \mathrm{mg}$ of $\mathrm{GAE} / \mathrm{g}$ of propolis for $M$. quadrifasciata 

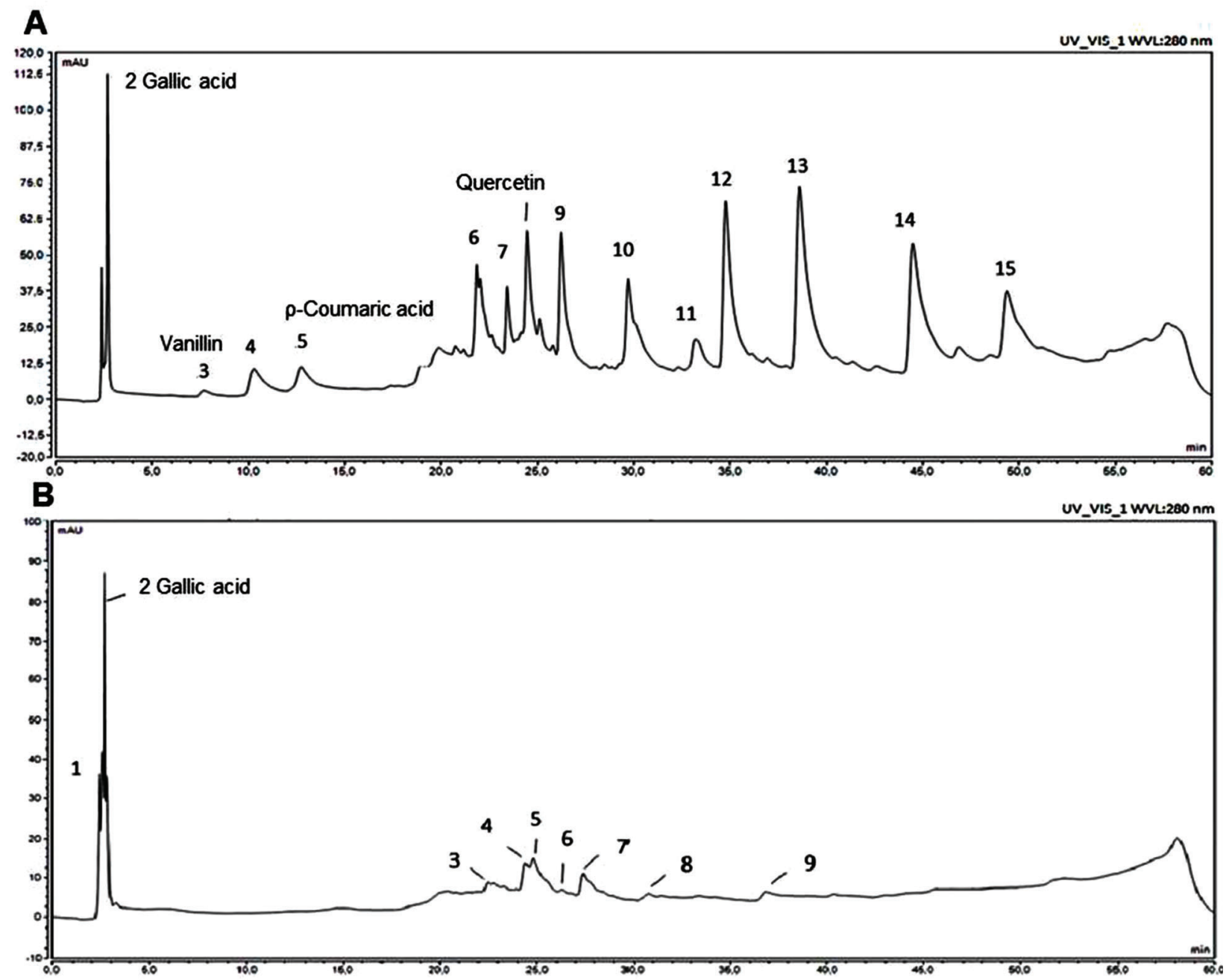

Figure 1. HPLC-DAD $(280 \mathrm{~nm})$ chromatograms of the ethanolic extract of propolis using a C18-reversed phase column at $40^{\circ} \mathrm{C}$. A, M. quadrifasciata quadrifasciata peaks: 2-gallic acid ( $\mathrm{Rt}=2.68 \mathrm{~min})$, 3-vanillin ( $\mathrm{Rt}=7.67 \mathrm{~min}), 5$ - $\rho$-coumaric acid $(\mathrm{Rt}=12.73 \mathrm{~min})$, and 8-quercetin ( $\mathrm{Rt}=24.45 \mathrm{~min})$. B, T. angustula peak: 2-gallic acid ( $\mathrm{Rt}=2.69 \mathrm{~min})$. Rt: retention time. The peaks not cited are from unidentified compounds.

quadrifasciata and T. angustula, respectively. The flavonoid content was $0.14 \pm 0.03 \mathrm{mg} Q E / g$ of propolis for M. quadrifasciata quadrifasciata and $0.15 \pm 0.02 \mathrm{mg} \mathrm{QE} / \mathrm{g}$ of propolis for T. angustula. Only the polyphenol content was significantly different between the EEPs of the two bee species $(P<0.001)$.

\section{HPLC-DAD analysis}

HPLC chromatograms are presented in Figure $1 \mathrm{~A}$ and $1 \mathrm{~B}$. The analysis of the propolis from M. quadrifasciata quadrifasciata revealed the presence of gallic acid, vanillin, $\rho$-coumaric acid, and quercetin (retention times: $2.68,7.67,12.73$, and $24.45 \mathrm{~min}$, respectively). The analysis of the propolis from $T$. angustula revealed the presence of gallic acid (retention time: $2.68 \mathrm{~min}$ ).

\section{UPLC analysis/ESI-QTOF-MS}

UPLC-ESI-QTOF-MS/MS techniques showed a good separation profile for the EEP from $M$. quadrifasciata quadrifasciata. The analysis in positive and negative ionization modes revealed the presence of 26 diterpenes skeletons as major components, of which 17 were characterized (Table 1). The identification was supported by data found in the literature, based on which some of these propolis constituents were found to be sesquiterpene metabolites, triterpenes, stilbenes, and polyphenols.

The major component detected at $\mathrm{m} / \mathrm{z} 319.2274$ $\left[\mathrm{C}_{20} \mathrm{H}_{32} \mathrm{O}_{3}-\mathrm{H}\right]^{-}\left(\mathrm{t}_{R} 6.95 \mathrm{~min}\right)$ in the negative ionization mode was identified as isocupressic acid (20). Only two fragments were obtained from this precursor $(\mathrm{m} / \mathrm{z} 231.1707$ and 300 . 2069). The fragment $\mathrm{m} / \mathrm{z} 300.2069$ corresponded to loss of 
Table 1. Identification of compounds in ethanolic crude extract from the propolis of M. quadrifasciata quadrifasciata by UPLC-MS/MS and ESI-QTOF/MS analysis, in negative and positive mode.

\begin{tabular}{|c|c|c|c|c|c|c|}
\hline$t_{R}(\min )$ & $\begin{array}{c}\text { Mol. } \\
\text { weight }(\mathrm{m} / \mathrm{z})\end{array}$ & $\begin{array}{c}\text { Calc. } \\
\text { mass }(\mathrm{m} / \mathrm{z})\end{array}$ & $\begin{array}{l}\text { Elem. } \\
\text { comp. }\end{array}$ & Fragments $(\mathrm{m} / \mathrm{z})$ & Proposed structure & Ref. \\
\hline \multicolumn{7}{|c|}{ ESI- ([M-H]') } \\
\hline 4.71 & 291.1586 & 291.1596 & $\mathrm{C}_{17} \mathrm{H}_{24} \mathrm{O}_{4}$ & $\begin{array}{c}273.1490,245.1571,229.1601 \\
213.1283\end{array}$ & pinusenocarp & 35 \\
\hline 5.34 & 335.2220 & 335.2222 & $\mathrm{C}_{20} \mathrm{H}_{32} \mathrm{O}_{4}$ & $317.2103,299.1998$ & junicedric acid or salvicin & 36 \\
\hline 5.48 & 331.1913 & 331.1909 & $\mathrm{C}_{20} \mathrm{H}_{28} \mathrm{O}_{4}$ & $\begin{array}{c}313.1810,269.1823,255.1380 \\
227.1429\end{array}$ & inumakiol D & 37 \\
\hline 6.95 & 319.2274 & 319.2273 & $\mathrm{C}_{20} \mathrm{H}_{32} \mathrm{O}_{3}$ & $300.2069,231.1707$ & isocupressic acid & 20 \\
\hline 7.36 & 317.2103 & 317.2117 & $\mathrm{C}_{20} \mathrm{H}_{30} \mathrm{O}_{3}$ & $299.1998,271.1856,221.1538$ & agathalic acid & 20 \\
\hline 7.50 & 317.2103 & 317.2117 & $\mathrm{C}_{20} \mathrm{H}_{30} \mathrm{O}_{3}$ & $\begin{array}{l}299.1998,287.1987,273.2234 \\
271.2092,257.1837,255.2166 \\
253.2015\end{array}$ & $\begin{array}{c}\text { 15-oxolabda-8(17), 13Z-diene- } \\
\text { 19-oic acid or (15-oxolabda- } \\
\text { (17),13E-dien-19-oic acid) } \\
\text { or agathalic acid }\end{array}$ & 20,36 \\
\hline 9.45 & 347.2197 & 347.2222 & $\mathrm{C}_{21} \mathrm{H}_{32} \mathrm{O}_{4}$ & - & 15-agathic acid methyl ester & 20 \\
\hline 11.28 & 301.2157 & 301.2171 & $\mathrm{C}_{20} \mathrm{H}_{30} \mathrm{O}_{2}$ & - & $\begin{array}{l}\text { trans-communic acid or } \\
\text { pimaric acid }\end{array}$ & 36 \\
\hline \multicolumn{7}{|c|}{$\mathrm{ESI}+\left([\mathrm{M}+\mathrm{H}]^{+}\right)$} \\
\hline 6.95 & 303.2305 & 303.2324 & $\mathrm{C}_{20} \mathrm{H}_{30} \mathrm{O}_{2}$ & $\begin{array}{c}285.2144,267.2139,257.2272 \\
215.1833,201.1677\end{array}$ & $\begin{array}{c}\text { hinokiol, or } 3 \beta \text {-hydroxytotarol or } \\
\text { totara- } 8,11,13 \text {-triene- } 7 \alpha, 13 \text {-diol }\end{array}$ & 21,22 \\
\hline 7.36 & 301.2183 & 301.2168 & $\mathrm{C}_{20} \mathrm{H}_{28} \mathrm{O}_{2}$ & $\begin{array}{c}283.2144,255.2140,199.1512 \\
185.1365,173.1339\end{array}$ & angustanoic acid $A$ & 38 \\
\hline 7.50 & 301.2183 & 301.2168 & $\mathrm{C}_{20} \mathrm{H}_{28} \mathrm{O}_{2}$ & $\begin{array}{c}283.2144,255.2140,199.1512 \\
185.1365,173.1339\end{array}$ & Related to angustanoic acid $A$ & - \\
\hline 7.91 & 315.1970 & 315.1960 & $\mathrm{C}_{20} \mathrm{H}_{26} \mathrm{O}_{3}$ & $\begin{array}{c}271.2100,227.1460,213.1305 \\
199.1137,187.1145,175.1145 \\
171.0843,149.0993\end{array}$ & artepillin C methyl ether & - \\
\hline 8.09 & 327.1584 & 327.1596 & $\mathrm{C}_{20} \mathrm{H}_{22} \mathrm{O}_{4}$ & - & $\begin{array}{c}\text { (E)-4-(3-methyl-2-buten-1-yl)- } \\
\text { 3,3',5-trihydroxy-4'- } \\
\text { methoxystilbene or (E)-2- } \\
\text { (3-methyl-2-buten-1-yl)-3', } 4^{\prime} \\
\text { 5-trihydroxy-3-methoxystilbene }\end{array}$ & 39 \\
\hline 8.35 & 327.1584 & 327.1596 & $\mathrm{C}_{20} \mathrm{H}_{22} \mathrm{O}_{4}$ & - & $\begin{array}{l}\text { related to (E)-4-(3-methyl- } \\
\text { 2-buten-1-yl)-3,3',5-trihydroxy- } \\
\text { 4'-methoxystilbene }\end{array}$ & 39 \\
\hline 8.53 & 287.2378 & 287.2375 & $\mathrm{C}_{20} \mathrm{H}_{30} \mathrm{O}$ & - & trans-totarol or trans-communal & 36 \\
\hline 11.83 & 303.2305 & 303.2324 & $\mathrm{C}_{20} \mathrm{H}_{30} \mathrm{O}_{2}$ & $\begin{array}{c}257.2305,255.2142,201.1677 \\
187.1508,173.1366,149.1343 \\
135.1183,123.1199\end{array}$ & $\begin{array}{l}\text { related to trans-communic acid or } \\
\text { pimaric acid }\end{array}$ & 36 \\
\hline 13.96 & 441.3735 & 441.3733 & $\mathrm{C}_{30} \mathrm{H}_{48} \mathrm{O}_{2}$ & - & $\begin{array}{l}\text { 24(E)-3 } 3 \text {-hydroxycycloart- } \\
\text { 24-ene-26-al }\end{array}$ & 40 \\
\hline
\end{tabular}

the neutral species $\mathrm{H}_{2}$ and the $\mathrm{OH}$ radical while the other was found after considering the decarboxylation (loss of $\mathrm{CO}_{2}$ ), the elimination of $\mathrm{CH}_{4}$ and $\mathrm{C}_{2} \mathrm{H}_{4}$ resulting in the opening of the left ring of the decalin portion.

The structure of hinokiol, $3 \beta$-hydroxytotarol, or totara$8,11,13$-triene-7 $\alpha, 13$-diol $(21,22)$ was proposed for the major compound detected in the positive mode at $6.95 \mathrm{~min}$ $\left(\mathrm{m} / \mathrm{z}\right.$ 303.2305: $\left.\left[\mathrm{C}_{20} \mathrm{H}_{30} \mathrm{O}_{2}+\mathrm{H}\right]^{+}\right)$. In fact, all three compounds could successively loose two molecules of $\mathrm{H}_{2} \mathrm{O}$ to generate $\mathrm{m} / \mathrm{z} 285.2242\left[\mathrm{M}+\mathrm{H}-\mathrm{H}_{2} \mathrm{O}\right]^{+}$and $\mathrm{m} / \mathrm{z} 267.2139$ $\left[\mathrm{M}+\mathrm{H}-2 \mathrm{H}_{2} \mathrm{O}\right]^{+}$, respectively. Their phenol could also isomerize to a ketone and a ring constriction could occur by elimination of carbon monoxide to give $\mathrm{m} / \mathrm{z} 255.2142$ $\left[\mathrm{M}+\mathrm{H}-\mathrm{H}_{2} \mathrm{O}-\mathrm{CO}\right]^{+}$. Furthermore, an isopropylene moiety could also be eliminated from the precursor $\mathrm{m} / \mathrm{z} 255.2142$ yielding $\mathrm{m} / \mathrm{z} 215.1833\left[\mathrm{M}+\mathrm{H}-\mathrm{H}_{2} \mathrm{O}-\mathrm{CO}-\mathrm{C}_{3} \mathrm{H}_{6}\right]^{+}$. 


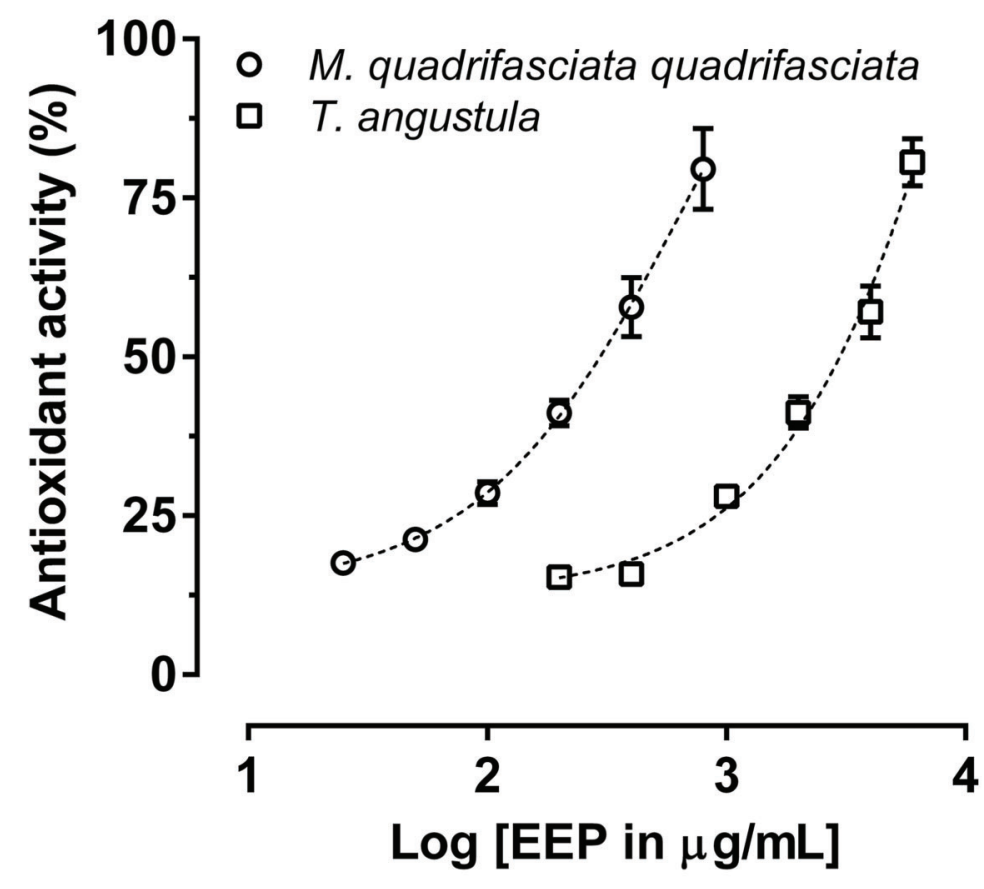

Figure 2. Effect of ethanolic extracts of propolis (EEP) from M. quadrifasciata quadrifasciata and $T$. angustula on DPPH radical scavenging. $\mathrm{IC}_{50}$ values were obtained by nonlinear regression; M. quadrifasciata quadrifasciata: $\mathrm{IC}_{50}=241.8 \mu \mathrm{g} / \mathrm{mL}$ and $T$. angustula: $\mathrm{IC}_{50}=2433.0 \mu \mathrm{g} / \mathrm{mL}$. Data are reported as means \pm SE of three independent experiments performed in triplicate.
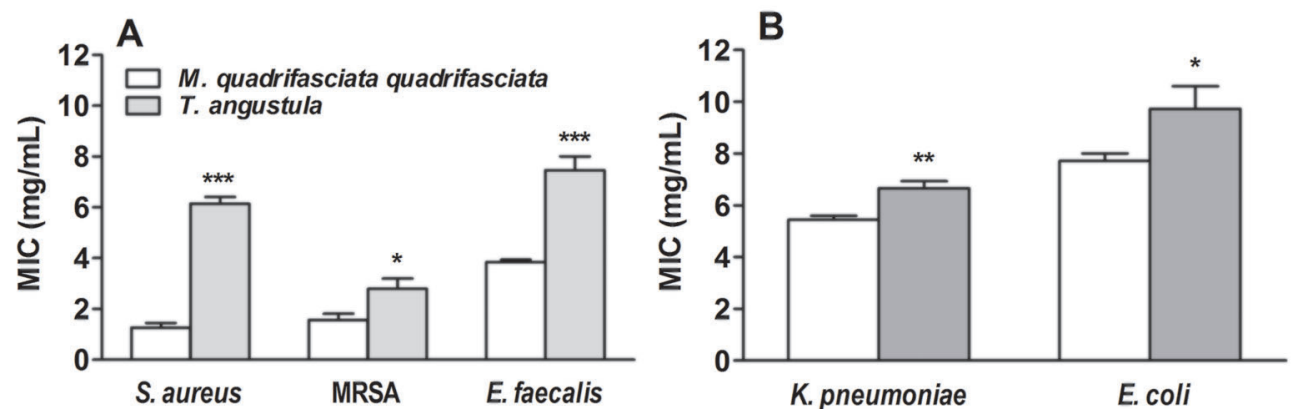

Figure 3. Susceptibility of bacterial strains to ethanolic extracts of propolis in minimal inhibitory concentration (MIC). $A$, Gram-positive bacteria: S. aureus (ATCC 25923), methicillin-resistant S. aureus (MRSA, clinical isolate), and E. faecalis (ATCC 29212); B, Gramnegative bacteria: $K$. pneumoniae (ATCC 23883) and E. coli (ATCC 25922). Data are reported as means \pm SE of 3-5 independent experiments performed in triplicate. ${ }^{*} \mathrm{P}<0.05,{ }^{* *} \mathrm{P}<0.01$ and ${ }^{* * *} \mathrm{P}<0.001$ compared to $M$. quadrifasciata quadrifasciata (ANOVA followed by Bonferroni's test).

\section{Antioxidant activity}

The results reported in Figure 2 show that both EEPs had dose-dependent antioxidant activity. Moreover, the EEP from M. quadrifasciata quadrifasciata $\left[\mathrm{IC}_{50}=241.8\right.$ (203.1 to 287.7$) \mu \mathrm{g} / \mathrm{mL}$ ] was ten-fold more potent than the EEP from $T$. angustula $\left[\mathrm{IC}_{50}=2433.0(2086.0\right.$ to 2838.0$\left.\left.) \mu \mathrm{g} / \mathrm{mL}\right)\right]$.

\section{Determination of MIC}

The MIC values of the extracts for gram-positive and gram-negative bacteria are shown in Figure $3 \mathrm{~A}$ and $3 \mathrm{~B}$. Gram-positive bacteria ( $E$. faecalis, S. aureus and MRSA) were more sensitive than gram-negative bacteria $(E$. coli and $K$. pneumoniae) to both EEPs. In addition, the EEP from $M$. quadrifasciata quadrifasciata was more potent and efficacious than the EEP of $T$. angustula showing the lowest MIC values for all tested bacteria.

\section{Growth curve}

Considering the promising results in the MIC assay, we decided to investigate the effect of the EEP from $M$. quadrifasciata quadrifasciata on the growth of $S$. aureus (ATCC 25923) and E. coli (ATCC 25922) over time. Figure 4 shows that the inhibitory effect of $M$. quadrifasciata quadrifasciata (1 MIC) EEP on $S$. aureus growth was 

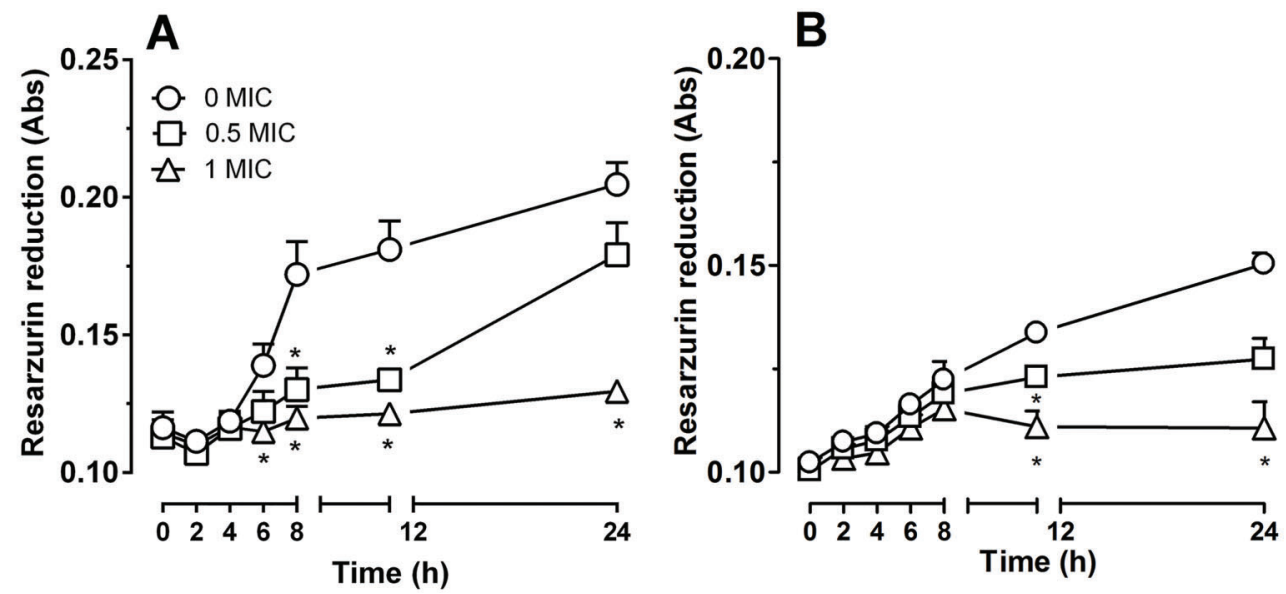

Figure 4. Effect of ethanolic extracts of propolis from M. quadrifasciata quadrifasciata on growth curve assay. Absorbance readings for assays with $S$. aureus $(A)$ and $E$. coli $(B)$. Data are reported as means \pm SE of three independent experiments performed in triplicate. ${ }^{*} \mathrm{P}<0.05$ compared to respective control (t-test).

Table 2. Effect of ethanolic extracts of propolis (EEP) from M. quadrifasciata quadrifasciata on cell constituents release of $S$. aureus and $E$. coli after $4 \mathrm{~h}$.

\begin{tabular}{lccc}
\hline Bacterial Strains & \multicolumn{2}{c}{ Cell Constituents Release $\left(\mathrm{OD}_{260 \mathrm{~nm}}\right)$} & $\begin{array}{c}\text { Relative Release } \\
\text { (EEP/Control) }\end{array}$ \\
\cline { 2 - 3 } & Control & EEP $(1 \times \mathrm{MIC})$ & \\
\hline S. aureus & $0.041 \pm 0.004$ & $0.260 \pm 0.033^{*}$ & $6.61 \pm 1.211$ \\
E. coli & $0.149 \pm 0.017$ & $0.811 \pm 0.054^{* *}$ & $5.65 \pm 0.585$ \\
\hline
\end{tabular}

Data are reported as means \pm SE of three independent experiments performed in triplicate. ${ }^{*} \mathrm{P}=0.0004$ and ${ }^{* *} \mathrm{P}=0.0001$ compared to respective control $(t$-test).

time-dependent and occurred in about $6 \mathrm{~h}$. On the other hand, the inhibitory effect of the extract on the growth of E. coli took $12 \mathrm{~h}$ to occur.

\section{Integrity of cell membrane}

The results presented in Table 2 show that the EEP from $M$. quadrifasciata quadrifasciata (1 MIC) increased 6.6- and 5.6-fold the leakage of cell constituents of $S$. aureus and $E$. coli, respectively, suggesting that it causes an irreversible damage of the bacterial cell membrane, leading to cell death.

\section{Discussion}

The current study revealed that EEPs from M. quadrifasciata quadrifasciata and $T$. angustula had antimicrobial activity against gram-positive and gram-negative bacteria and antioxidant activity. The chemical analysis of the EEPs revealed the presence of terpenoids, flavonoids, and polyphenols, which were more abundant in the EEP from $M$. quadrifasciata quadrifasciata (Figure 1).

The more prominent effect of EEPs against grampositive than against gram-negative bacteria, as assessed by the MIC assay, agrees with previous studies that have shown that propolis from stingless bees $(7,9,23)$ and from Apis mellifera (6) has antimicrobial activity, particularly against gram-positive bacteria. In this regard, the currently reported activity against MRSA is particularly interesting due to the present scenario of recrudescence of resistant S. aureus strains (12). The MICs estimated in the current study for gram-positive bacteria are similar to the estimated MICs of EEPs from other stingless bees, around $2-3 \mathrm{mg} / \mathrm{mL}$ for $S$. aureus $(9,23)$, including MRSA. Previous studies that have used the same experimental protocol of MIC determination used in our study could not determine a MIC for EEP against gramnegative bacteria (9). However, we found MIC values for EEP against gram-negative bacteria between 5 and $7 \mathrm{mg} / \mathrm{mL}$ in our samples, also indicating some activity of EEP from $M$. quadrifasciata quadrifasciata and $T$. angustula against gram-negative bacteria. Considering the estimated MICs in our assays, the EEP from M. quadrifasciata quadrifasciata was more potent than the EEP from $T$. angustula as an antimicrobial agent. Although the EEPs showed important antimicrobial activity for all tested strains, MICs values obtained ( 2 to $7 \mathrm{mg} / \mathrm{mL}$ ) can 
be considered high, conferring a reasonable antimicrobial activity.

Due to its better antimicrobial activity, the EEP from M. quadrifasciata quadrifasciata was chosen for additional tests: growth curve, release of cell constituents, and mass spectrometry experiments. To analyze the effect of the EEP from $M$. quadrifasciata quadrifasciata against $S$. aureus and $E$. coli over time, a growth curve assay was performed in the absence or presence of the EEP (1 MIC). S. aureus was more susceptible to EEP than E. coli also in this assay. Accordingly, while a significant growth reduction was found at 6 hours for $S$. aureus, 12 hours were necessary to show a significant growth reduction for $E$. coli, compared to their respective controls (0 MIC).

Although some authors attribute the bacteriostatic and bactericidal activity of propolis to the inhibition of protein synthesis and prevention of cell division (24), its nature and complexity complicate the identification of a mechanism of action. In this study, we performed a cell constituent release assay to investigate a possible mechanism of action for EEP, i.e. disruption of the cell membrane, which would cause the release of large molecules to the medium. The assay revealed a significant release of intracellular constituents of $S$. aureus and $E$. coli to the incubation medium in the presence of the EEP from M. quadrifasciata quadrifasciata (Table 2), supporting that it causes cell lysis.

Aiming to further elucidate the composition of EEP from $M$. quadrifasciata quadrifasciata, an UPLC coupled with mass spectrometry assay was carried out. The assay showed 26 diterpene skeletons as major components and, based on the literature, it was possible to suggest 17 structures. Among these, the following compounds are particularly relevant: one of elemental composition $\mathrm{C}_{20} \mathrm{H}_{30} \mathrm{O}_{2}$, which may be a hinokiol or totarol derivative, isocupressic acid, and artepillin $\mathrm{C}$ methyl ester. The presence of totarol and possibly a derivative is consistent with our antibacterial findings. Totarol is a highly hydrophobic diterpenoid with a high phospholipid/water partition coefficient, capable of interfering with the structural integrity of the membrane of bacteria and causing cell lysis (25). In addition, it decreases the expression of penicillin binding protein $2 \mathrm{a}$, a protein involved in penicillin resistance of MRSA (26). Recent evidence supports that totarol inhibits hemolytic proteins and enterotoxins secreted by $S$. aureus (27) and has potential application in clinical therapy and food decay prevention. In line with this view, hinokiol, also an identified component of EEP from M. quadrifasciata quadrifasciata, has been described as having antimicrobial, antitumoral, antioxidant and anti-inflammatory activity $(28,29)$. Therefore, hinokiol may also be involved in the antimicrobial action of EEP from $M$. quadrifasciata quadrifasciata. In addition, isocupressic acid, also a component of propolis, has antimicrobial activity (30) and may play a role in the antibiotic effect of EEP from $M$. quadrifasciata quadrifasciata. The UPLC-MS also revealed the presence of artepillin $\mathrm{C}$ in the EEP from $M$. quadrifasciata quadrifasciata. Artepillin $\mathrm{C}$ has been pointed out as the possible active component responsible for the antimicrobial and antioxidant activity of green propolis (31), similarly to totarol, interacting with cell membrane and creating point defects in its structure (32). Therefore, one might consider that artepillin $C$ is involved in the current antimicrobial effect of EEP from M. quadrifasciata quadrifasciata.

It is well known that propolis from different bee species contain significant amount of antioxidants (5). Therefore, we decided to comparatively assess the antioxidant activity and total content of phenols and flavonoids in the EEPs from $M$. quadrifasciata quadrifasciata and T. angustula. The EEP from $M$. quadrifasciata quadrifasciata presented higher antioxidant activity than the EEP form $T$. angustula in the DPPH assay $\left(\mathrm{IC}_{50}=241.8\right.$ and $2433.0 \mu \mathrm{g} / \mathrm{mL}$, respectively). Interestingly, Bonamigo et al. (33) also demonstrated that ethanol extracts of propolis obtained from the stingless bees $M$. quadrifasciata anthidioides had a higher antioxidant capacity in the DPPH $\left(\mathrm{IC}_{50}=60.9 \mu \mathrm{g} / \mathrm{mL}\right)$ and ABTS $\left(\mathrm{IC}_{50}=13.4 \mu \mathrm{g} / \mathrm{mL}\right)$ assay compared to Scaptotrigona depilis. Considering the antioxidant profile of the propolis extract obtained from the $M$. quadrifasciata anthidioides and M. quadrifasciata quadrifasciata in the DPPH test, we can observe that the $M$. quadrifasciata anthidioides was about 3.9-fold more potent than the M. quadrifasciata quadrifasciata. Based on the above results, we can also suggest that the antioxidant activity present in propolis seemed to depend on the genus and species of bees, considering that the potency and efficacy of the propolis obtained from the bees belonging to the Melipona genus ( $M$. quadrifasciata anthidioides and $M$. quadrifasciata quadrifasciata) were higher than Tetragonisca ( $T$. angustula) and Scaptotrigona (S. depilis), respectively.

The differences in the chemical composition of propolis extracts in the same region may be related to species of bees and the preference for a particular plant species to elaborate the propolis $(2,33)$. Moreover, the genetic variability of bee species influences the chemical composition of propolis, resulting in different biological activities (2). Accordingly, the EEP from $M$. quadrifasciata quadrifasciata presented a higher concentration of total phenols and flavonoids, reinforcing the direct correlation between phenol concentration and antioxidant activity established in the literature (34).

In conclusion, the data presented here showed that the chemical composition of propolis from stingless bees is complex and depends on the species, among other factors. The extract from $M$. quadrifasciata quadrifascita was more potent in promoting antioxidant and antibacterial activity compared to $T$. angustula extract. In addition, EEPs were more effective against gram-positive than against gram-negative strains, especially against $S$. aureus and MRSA, by a mechanism that involved the disturbance of bacterial cell membrane integrity. The current findings suggest that propolis from stingless bees may be a potential source of active compounds against MRSA. 


\section{Acknowledgments}

We thank Luis Celso Stafaniak for providing the propolis samples and his dedication in divulgating the importance of preserving the various species of stingless bees, and Dr. Rosmari Horner for providing the clinical isolate strain of MRSA. This research was supported by Conselho Nacional de Desenvolvimento Científico e Tecnológico (CNPq)/Brazil. ARSS, MM, and CFM are recipients of $\mathrm{CNPq}$ productivity fellowships.

\section{References}

1. Brasil, Ministério da Agricultura. Instrução Normativa $n^{\circ} 3-$ ANEXO VI - Regulamento técnico para a fixação de identidade e qualidade de própolis. Diário Oficial da República Federativa do Brasil. Brasilia, Jan 19, 2001. http://extranet. agricultura.gov.br/sislegis-consulta/consultarLegislacao.do? operacao=visualizar\&id $=1798$.

2. Bankova V, Popova M, Trusheva B. Propolis volatile compounds: chemical diversity and biological activity: a review. Chem Cent J 2014; 8: 28, doi: 10.1186/1752-153X8-28.

3. Miguel MG, Nunes S, Dandlen SA, Cavaco AM, Antunes MD. Phenols and antioxidant activity of hydro-alcoholic extracts of propolis from Algarve, South of Portugal. Food Chem Toxicol 2010; 48: 3418-3423, doi: 10.1016/j.fct.2010. 09.014 .

4. Tomazzoli MM, Neto RDP, Moresco R, Westphal L, Zeggio ARS, Specht L, et al. Discrimination of Brazilian propolis according to the seasoning using chemometrics and machine learning based on UV-Vis scanning data. $J$ Integr Bioinform 2015; 12: 279-291, doi: 10.1515/jib-2015-279.

5. Franchin M, da Cunha MG, Denny C, Napimoga MH, Cunha $\mathrm{TM}, \mathrm{Koo} \mathrm{H}$, et al. Geopropolis from Melipona scutellaris decreases the mechanical inflammatory hypernociception by inhibiting the production of IL-1beta and TNF-alpha. J Ethnopharmacol 2012; 143: 709-715, doi: 10.1016/j.jep.2012. 07.040 .

6. Silva JC, Rodrigues S, Feas X, Estevinho LM. Antimicrobial activity, phenolic profile and role in the inflammation of propolis. Food Chem Toxicol 2012; 50: 1790-1795, doi: 10.1016/j.fct.2012.02.097.

7. Liberio SA, Pereira AL, Dutra RP, Reis AS, Araujo MJ, Mattar NS, et al. Antimicrobial activity against oral pathogens and immunomodulatory effects and toxicity of geopropolis produced by the stingless bee Melipona fasciculata Smith. BMC Complement Altern Med 2011; 11: 108, doi: 10.1186/1472-6882-11-108.

8. Sforcin JM. Propolis and the immune system: a review. J Ethnopharmacol 2007; 113: 1-14, doi: 10.1016/j.jep.2007. 05.012.

9. Campos JF, dos Santos UP, Macorini LF, de Melo AM, Balestieri JB, Paredes-Gamero EJ, et al. Antimicrobial, antioxidant and cytotoxic activities of propolis from Melipona orbignyi (Hymenoptera, Apidae). Food Chem Toxicol 2014; 65: 374-380, doi: 10.1016/j.fct.2014.01.008.

10. Choudhari MK, Punekar SA, Ranade RV, Paknikar KM. Antimicrobial activity of stingless bee (Trigona sp.) propolis used in the folk medicine of Western Maharashtra, India. J Ethnopharmacol 2012; 141: 363-367, doi: 10.1016/j.jep. 2012.02.047.

11. Wojtyczka RD, Dziedzic A, Idzik D, Kepa M, Kubina R, Kabala-Dzik A, et al. Susceptibility of Staphylococcus aureus clinical isolates to propolis extract alone or in combination with antimmicrobial drugs. Molecules 2013; 18: 9623-9640, doi: 10.3390/molecules18089623.

12. Smith $\mathrm{R}$, Coast J. The true cost of antimicrobial resistance. BMJ 2013; 46: 1493, doi: 10.1136/bmj.f1493.

13. Velikova M, Bankova V, Marcucci MC, Tsvetkova I, Kujumgiev A. Chemical composition and biological activity of propolis from Brazilian meliponinae. Z Naturforsch C 2000; 55: 785-789.

14. Nogueira-Neto P. Vida e criação de abelhas indígenas sem ferrão. $1^{\text {st }}$ edn. São Paulo, Editora Nogueirapis, 1997.

15. Park YK, Ikegaki M, Abreu JAS, Alcici NMF. Estudo da preparação dos extratos de própolis e suas aplicações. Food Sci Technol 1998; 18: 313-318, doi: 10.1590/S010120611998000300011.

16. Frozza CO, Garcia CS, Gambato G, de Souza MD, Salvador M, Moura S, et al. Chemical characterization, antioxidant and cytotoxic activities of Brazilian red propolis. Food Chem Toxicol 2013; 52: 137-142, doi: 10.1016/j.fct.2012.11.013.

17. CLSI. Methods for dilution antimicrobial susceptibility tests for bacteria that grow aerobically; Approved Standard Ninth Edition. CLSI document M07-A9. WaynePA: Clinical and Laboratory Standards Institute; 2012.

18. Bueno-Silva B, Alencar SM, Koo H, Ikegaki M, Silva GV, Napimoga $\mathrm{MH}$, et al. Anti-inflammatory and antimicrobial evaluation of neovestitol and vestitol isolated from Brazilian red propolis. J Agric Food Chem 2013; 61: 4546-4550, doi: 10.1021/jf305468f.

19. Diao WR, Hu QP, Zhang H, Xu JG. Chemical composition, antibacterial activity and mechanism of action of essential oil from seeds of fennel (Foeniculum vulgare Mill.). Food Cont. 2014; 35: 109-116, doi: 10.1016/j.foodcont.2013.06.056.

20. Banskota AH, Tezuka Y, Prasain JK, Matsushige K, Saiki I, Kadota S. Chemical constituents of Brazilian propolis and their cytotoxic activities. J Nat Prod 1998; 61: 896-900, doi: $10.1021 / \mathrm{np} 980028 \mathrm{c}$.

21. Enzell CR, Wahlberg I. Mass spectrometric studies of diterpenes. 7. Aromatic diterpenes. Acta Chem Scand 1970; 24: 2498-2510, doi: 10.3891/acta.chem.scand.24-2498.

22. Wang YZ, Tang CP, Ke CQ, Weiss HC, Gesing ER, Ye Y. Diterpenoids from the pericarp of Platycladus orientalis. Phytochemistry 2008; 69: 518-526, doi: 10.1016/j.phytochem. 2007.07.023.

23. Miorin PL, Levy Junior NC, Custodio AR, Bretz WA, Marcucci MC. Antibacterial activity of honey and propolis from Apis mellifera and Tetragonisca angustula against Staphylococcus aureus. J Appl Microbiol 2003; 95: 913920, doi: 10.1046/j.1365-2672.2003.02050.x.

24. Fernandes-Junior A, Balestrin EC, Betoni JE, Orsi RO, da Cunha ML, Montelli AC. Propolis: anti-Staphylococcus aureus activity and synergism with antimicrobial drugs. Mem Inst Oswaldo Cruz 2005; 100: 563-566, doi: 10.1590/ S0074-02762005000500018. 
25. Micol V, Mateo CR, Shapiro S, Aranda FJ, Villalain J. Effects of (+)-totarol, a diterpenoid antibacterial agent, on phospholipid model membranes. Biochim Biophys Acta 2001; 511: 281-290, doi: 10.1016/S0005-2736(01)00284-X.

26. Nicolson K, Evans G, O'Toole PW. Potentiation of methicillin activity against methicillin-resistant Staphylococcus aureus by diterpenes. FEMS Microbiol Lett 1999; 179: 233-239, doi: 10.1111/j.1574-6968.1999.tb08733.x.

27. Shi C, Zhao X, Li W, Meng R, Liu Z, Liu M, et al. Inhibitory effect of totarol on exotoxin proteins hemolysin and enterotoxins secreted by Staphylococcus aureus. World J Microbiol Biotechnol 2015; 31: 1565-1573, doi: 10.1007/s11274-0151905-3.

28. Starks CM, Norman VL, Willians RB, Goering MG, Rice SM, O'Neil-Johson M., et al. Antibacterial activity of Taxodium ascendens diterpenes against methicillin-resistant Staphylococcus aureus. Nat Prod Commun 2014; 9: 1129-1130.

29. Wang SY, Wu JH, Shyur LF, Kuo YH, Chang ST. Antioxidant Activity of Abietane-Type Diterpenes from Heartwood of Taiwania cryptomerioides Hayata. Holzforschung 2002; 56: 487-492, doi: 10.1515/HF.2002.075.

30. Bankova V, Marcucci MC, Simova S, Nikolova N, Kujumgiev A, Popov S. Antibacterial diterpenic acids from Brazilian propolis. Z Naturforsch C 1996; 51: 277-280.

31. Veiga RS, Mendonça S, Mendes PB, Paulino N, Mimica NJ, Neto $A A$, et al. Artepillin $C$ and phenolic compounds responsible for antimicrobial and antioxidant acticity of green propolis and Baccharis dracunculifolia DC. J Appl Microbiol 2017; 122: 911-920, doi: 10.1111/jam.13400.

32. Pazin WM, Olivier DD, Vilanova N, Ramos AP, Voets IK, Soares $A E$, et al. Interaction of Artepillin $C$ with model membranes. Eur Biophys J 2016; 46: 383-393, doi: 10.1007/ s00249-016-1183-5.

33. Bonamigo $\mathrm{T}$, Campos JQ, Alfredo TM, Balestieri JBP, Cardoso CAL, Paredes-Gamero EJ, et al. Antioxidant, cytotoxic, and toxic activities of propolis from two native bess in Brazil: Scaptotrigona depilis and Melipona quadrifasciata anthiodioides. Oxid Med Cell Longev 2017; 2017: 1038153, doi: 10.1155/2017/1038153.

34. Duthie GG, Gardner PT, Kyle JA. Plant polyphenols: are they the new magic bullet? Proc Nutr Soc 2003; 62: 599-603, doi: 10.1079/PNS2003275.

35. Yang $X$, Zhang YC, Zhang $H$, Dong AJ, Zhao HT, et al. Diterpenoid acids from Pinus koraiensis. Chem Nat Compd 2010; 46: 227-229, doi: 10.1007/s10600-010-9575-8.

36. Popova MP, Chimou IB, Marekov IN, Bankova VS. Terpenes with antimicrobial activity from Cretan propolis. Phytochemistry 2009; 70: 1262-1271, doi: 10.1016/j.phytochem.2009. 07.025 .

37. Zhang L-C, Wu X-De, He J, Li Y, Zhang R-P, Zhao Q-S. Three new abietane diterpenoids from Podocarpus fleury. Phytochem Lett 2013; 6: 364-367, doi: 10.1016/j.phytol. 2013.04.003.

38. Sy LK, Brown GD. Abietane diterpenes from Illicium angustisepalum. J Nat Prod 1998; 61: 907-912.

39. Duke CC, Tran VH, Duke RK. Prenylated hydroxystilbenes. Patent No. WO2012/149608A1. The University of Sidney; 2012.

40. Li F, Awale S, Zhang H, Tezuka Y, Kadota HES. Chemical constituents of propolis from Myanmar and their preferential cytotoxicity against a human pancreatic cancer cell line. J Nat Prod 2009; 72: 1283-1287, doi: 10.1021/np9002433. 